Jurnal Ilmiah KONTEKSTUAL

Volume 3, No. 1, Agustus 2021, p. 1-7

\title{
MODEL PEMBELAJARAN DARING PESERTA DIDIK SEKOLAH DASAR DI MASA PANDEMI COVID-19
}

\section{ELEMENTARY SCHOOL STUDENTS ONLINE LEARNING MODEL IN THE COVID-19 PANDEMIC}

\author{
Moh. Toharudin*1, Dian Luthfiatul Amalia ${ }^{2}$ \\ 1,2 Program Studi Pendidikan Guru Sekolah Dasar, Fakultas Keguruan dan Ilmu Pendidikan, Universitas \\ Muhadi Setiabudi Brebes, Indonesia \\ e-mail:*2sunantoha12@gmail.com, 2dianluthfiatul@gmail.com
}

\begin{abstract}
ABSTRAK
Pandemi covid-19 menuntut semua aktivitas dilakukan secara daring termasuk pendidikan. Tujuan dari penelitian ini adalah untuk mendeskripsikan model belajar secara daring selama pandemi covid-19 dan mengetahui kendala dalam pembelajaran daring di sekolah dasar. Penelitian ini merupakan penelitian kualitatif studi kasus yang dilaksanakan di SDN Cikakak 01. Pengumpulan data menggunakan teknik wawancara, observasi dan dokumentasi. Informan dari penelitian ini yaitu guru kelas, peserta didik dan wali murid. Hasil menunjukkan bahwa model pembelajaran daring yang dilaksanakan SD Negeri Cikakak 01 Banjarharjo Brebes adalah blended daring dan luring. Pembelajaran daring dilakukan melalui grup whatsapp pada masing-masing kelas yang dikoordinir oleh guru kelas. Pelaksanaan pembelajaran daring, guru memberikan materi dengan foto-foto materi dan video youtube yang diunggah pada group whatsapp. Selanjutnya untuk penugasan juga melalui group Whatsapp dan dikumpulkan kesekolah sesuai dengan jadwal yang sudah dibuat. Kendala dalam pembelajaran daring melalui wahtsapp yaitu pembelajaran masih dirasa kurang efektif untuk muatan matematika dan kelas rendah.
\end{abstract}

Kata kunci: Model pembelajaran daring, sekolah dasar

\begin{abstract}
The COVID-19 pandemic requires all activities to be carried out online, including education. The purpose of this study was to describe the online learning model during the covid-19 pandemic and to find out the obstacles in online learning in elementary schools. This research is a case study qualitative research conducted at SDN Cikakak 01. Data collection uses interview, observation and documentation techniques. Informants from this research are class teachers, students and guardians of students. The results show that the online learning model implemented by SD Negeri Cikakak 01 Banjarharjo Brebes is blended online and offline. Online learning is carried out through WhatsApp groups in each class which is coordinated by the class teacher. In the implementation of online learning, the teacher provides material with photos of the material and YouTube videos uploaded to the whatsapp group. Furthermore, for assignments also through the Whatsapp group and collected at school according to the schedule that has been made. The obstacle in online learning through wahtsapp is that learning is still considered less effective for mathematics and low grade content.
\end{abstract}

Keywords: Online learning model, elementary school 
Jurnal Ilmiah KONTEKSTUAL, Volume.3, No.1, Agustus 2021, pp. 1-7

\section{PENDAHULUAN}

Pendidikan adalah bekal yang harus dimiliki manusia untuk menjalani kehidupannya. Pelaksanaan pendidikan, tentu perlu disesuaikan dengan perkembangan teknologi informasi dan komunikasi. Terlebih saat ini, di era industri 4.0 perkembangan teknologi informasi dan komunikasi sudah merambah keberbagai aspek, termasuk dalam bidang pendidikan. Keberadaaan teknologi informasi dan komunikasi ini juga akan memudahkan terlaksananya proses pembelajaran, terutama selama pandemi covid-19.

Pandemi covid-19 dalam sekejap telah mengubah banyak hal disemua aspek kehidupan. Perubahan ini juga berimbas pada sistem pembelajaran di sekolah, yang semula dilaksanakan secara tatap muka, diubah menjadi daring. Proses pembelajaran daring tentu memerlukan sentuhan teknologi, informasi, dan komunikasi, seperti penggunaan gawai, televisi, hingga penggunaan platform-platform online yang dapat mendukung pembelajaran.

Penelitian terdahulu menyebutkan, pembelajaran daring menimbulkan beberapa dampak. Dampak tersebut diantaranya peserta didik menjadi jenuh dan bosan, serta pembelajaran juga menjadi kurang efektif, khususnya di Sekolah Dasar [1]. Oleh sebab itu, diperlukan suatu model yang dapat mendukung pembelajaran daring. Ketepatan pemilihan dan penerapan model pembelajaran daring yang dilakukan menjadi kunci keberhasilan pembelajaran.

Ada banyak hal yang harus diperhatikan dalam memilih model pembelajaran. Secara umum, model pembelajaran memiliki empat ciri khas, yaitu disusun oleh pendidik secara rasional, memiliki tujuan yang hendak dicapai, serta terdapat langkah-langkah yang jelas, dan didukung dengan lingkungan pembelajaran yang mendukung [2]. Pemilihan dan penerapan model pembelajaran setidaknya memenuhi unsur-unsur yang menjadi ciri khas model pembelajaran sekalipun pembelajaran dilaksanakan secara daring.

Model pembelajaran daring dilakukan secara online lewat gawai atau perangkat pendukung lainnya, melalui platform yang juga dapat diakses secara online. Platform tersebut diantaranya whatsapp, google classroom, google meet, zoom atau platform yang lainnya yang dianggap mudah digunakan dalam pembelajaran daring [3]. Platform yang mudah digunakan dan perangkat yang mendukung, tentu menjadi kunci keberhasilan model pembelajaran daring, mengingat dalam pembelajaran daring guru tidak secara langsung bertatap muka denga peserta didik. Dengan demikan, penerapan model pembelajaran daring dapat dilakukan dengan dukungan perangkat dan platform yang tepat.

Selain dukungan perangkat dan platform yang tepat, pelaksanaan pembelajaran daring juga memerlukan dukungan dari berbagai pihak. Dukungan tersebut berupa kerjasama yang baik antara guru, peserta didik, dan orang tua sehingga pembelajaran daring dapat terlaksana dengan baik [4]. Terlebih pada saat pandemi Covid-19 pembelajaran secara tatap muka tidak dapat dilaksakan, sehingga kerjasama yang baik ini akan membantu kelancaran pelaksanaan pembelajaran. Penelitian ini sangat perlu untuk dilakukan karena dapat mendasari guru dapat mengembangkan model pembelajaran daring yang tepat bagi peserta didik. Mengingat penelitian ini bertujuan untuk mendeskripsikan model pembelajaran daring peserta didik dan kendala pembelajaran, selama pandemi covid-19.

\section{METODE PENELITIAN}

Penelitian ini dilaksanakan di SD Negeri Cikakak 01 Kecamatan Banjarharjo Kabupaten Brebes, pada bulan Agustus sampai Oktober 2020. Analisis data yang digunakan yaitu analisis triangulasi sumber dan metode. Triangulasi pada hakikatnya merupakan pendekatan multi metode yang dilakukan peneliti pada saat mengumpulkan dan menganalisi data. Triangulasi sumber dilakukan dengan membandingkan data hasil pengamatan dengan data hasil wawancara, sementara itu, triangulasi metode merupakan pengecekan derajat kepercayaan hasil penelitian [5]. 
Jurnal Ilmiah KONTEKSTUAL, Volume.3, No.1, Agustus 2021, pp. 1-7

Alat untuk pengumpulan datanya menggunakan wawancara dan dokumentasi. Variabel dalam penelitian ini model pembelajaran daring. Sedangkan subyek penelitiannya terdiri dari guru, peserta didik, dan wali murid. Berikut adalah tabel profil informan penelitian:

Tabel 1. Profil informan

\begin{tabular}{lll}
\hline Inisial & $\begin{array}{c}\text { Jenis Kelamin } \\
\text { GR 1 }\end{array}$ & \multicolumn{1}{c}{ Status } \\
\hline PR 2 & Perempuan & Guru \\
\hline SW 1 & Laki-laki & Guru \\
\hline SW 2 & Perempuan & Peserta didik \\
\hline SW 3 & Perempuan & Peserta didik \\
\hline SW 4 & Perempuan & Peserta didik \\
SW 5 & Perempuan & Peserta didik \\
\hline SW 6 & Perempuan & Peserta didik \\
\hline WM 1 & Perempuan & Wali Murid \\
WM 2 & Perempuan & Wali Murid \\
\hline WM 3 & Perempuan & Wali Murid \\
\hline WM 4 & Perempuan & Wali Murid \\
WM 5 & Perempuan & Wali Murid \\
\hline
\end{tabular}

Subjek penelitian dipilih secara acak dari berbagai unsur yang meliputi guru, peserta didik, dan wali murid. Guru yang menjadi subjek adalah guru kelas 3 dan 4, peserta didik dari kelas IV, dan wali murid yang dipilih secara acak.

\section{HASIL DAN PEMBAHASAN}

\section{Hasil Penelitian}

\section{Model Pembelajaran Daring di SD Negeri Cikakak 01}

Model pembelajaran daring yang dilaksanakan di SD Negeri Cikakak 01 cukup bervariasi. Guruguru lebih banyak menggunakan platform whatsapp mengingat kemudahan penggunaannya. Hasil wawancara dengan GR 1, salah satu guru kelas di SD Negeri Cikakak 01 mengemukakan mekanisme pembelajaran daring yang dilaksankan melalui whatsapp sebagai berikut

Peserta didik diberi materi dan tugas melalui grup whatsapp. Kemudian setelah selesai dikerjakan peserta didik datang ke sekolah untuk mengumpulkan tugas atau dikirim ke grup whatsapp tersebut dalam bentuk foto.

SD Negeri Cikakak 01 menggunakan sistem blended dalam penerapan model pembelajaran daring. Artinya pembelajaran dilaksanakan secara daring tetapi peserta didik tetap melaksanakan sebagian kecil kegiatan secara luring atau offline dengan protokol kesehatan yang ketat.

Sistem blended dalam pelaksanaan pembelajaran selama pandemi covid-19 juga ditegaskan oleh GR 2, selaku guru kelas IV. Hasil wawancara menyebutkan bahwa. "setelah tugas diberikan lalu, pada hari yang sudah dijadwalkan peserta didik kesekolah untuk mengumpulkan tugas." Pada saat peserta didik datang ke sekolah, guru-guru juga menyisipkan materi-materi yang belum dikuasai peserta didik, disamping itu disisipkan juga arahan dan motivasi kepada peserta didik. Hal ini dilakukan untuk meminimalisir kendala pelaksanaan pembelajaran daring selama pandemi covid-19.

Peserta didik sebagai salah satu informan juga memberikan pernyataan yang sama terkait mekanisme pembelajaran daring. Adapun hasil wawancara dengan SW 3, salah satu peserta didik adalah sebagai berikut.

Guru memberikan tugas lewat foto dan dikumpulkan langsung ke sekolah sesuai jadwal yang ditentukan dan juga terkadang dikumpulkan hanya lewat foto. Nilai kan diberi tahu ketika berngkat sekolah.

Terdapat beberapa kegiatan yang disisipkan oleh guru selama peserta didik melaksanakan kegiatan secara luring, meski dengan waktu yang cukup terbatas. 
Jurnal Ilmiah KONTEKSTUAL, Volume.3, No.1, Agustus 2021, pp. 1-7

Selain penggunaan whatsapp sebagai platform pembelajaran daring, penyampaian materi pembelajaran juga telah didukung dengan berbagai media pembelajaran. Hasil wawancara dengan GR 2, adalah sebagai berikut.

Pembelajaran selama pandemi menggunakan Lembar Kerja Peserta didik (LKS).

Akan tetapi, penjelasannya selama pembelajaran daring menggunakan video youtube, foto-foto materi.

Penggunaan media dalam pembelajaran daring ini sudah cukup bervariasi, mulai dari media offline seperti buku-buku pendukung, termasuk LKS, hingga media yang dapat diakes secara online seperti video, youtube, dan foto-foto yang mendukung materi pelajaran.

\section{Kendala Pembelajaran Daring di SD Negeri Cikakak 01}

Pembelajaran daring adalah sesuatu yang baru, tentu saja memerlukan berbagai penyesuaian dan tidak sedikit menimbulkan beberapa kendala, baik dari sisi guru, peserta didik, maupun wali murid. Kendala-kendala pembelajaran daring ini cukup bervariasi. Kendala pembelajaran daring sisi guru sendiri, GK 1 selaku salah satu guru yang menjadi subjek penelitian mengemukakan kendala pembelajaran daring, sebagai berikut.

Kendala yang terjadi yaitu tidak semua peserta didik dapat dijangkau dan kesulitan dalam menerangkan materi yang akan diajarkan terutama pelajaran matematika.

Pembelajaran secara daring juga kurang efektif karena peserta didik kurang paham materi yang sudah disampaikan oleh guru. Peserta didik juga tidak semuanya mengumpulakan tugas.

Guru GK 1 mengalami kesulitan saat menyampaikan muatan matematika, disamping itu peserta didik juga tidak semuanya mengumpulkan tugas, sehingga dianggap kurang efektif. Hal ini karena guru tidak mengetahui peserta didik yang sudah memahami materi dan yang belum memahami materi.

Kurang efektifnya pembelajaran daring ini juga dikeluhkan oleh GK 2, khususnya di kelas rendah. Hasil wawancara menyebutkan sebagai berikut.

Dalam pemebalajaran daring kurang efektif untuk kelas rendah karena terkadang tidak memahami materi yang telah disampaikan. Kendala yang terjadi selama pembelajran daring yaitu tidak menjangkau peserta didik secara keseluruhan. Tugas ada yang mengumpulkan dan ada yang tidak mengumpulkan sama sekali. Karena tidak semua peserta didik orang tuanya mempunyai gawai.

Keterbatasan sarana menjadi kendala yang menjadikan pembelajaran daring kurang efektif menurut GK 2. Terlebih di kelas rendah yang peserta didiknya masih belum dapat membaca dan menulis, juga menjadi tantangan sekaligus kendala pembelajaran daring yang dialami oleh GK 2 .

Lebih lanjut, cukup bervariasinya media yang digunakan oleh guru selama pembelajaran daring, tidak lantas membuat peserta didik serta merta memahami materi. Hasil wawancara dengan SW 1, salah seorang peserta didik menyebutkan sebagai berikut.

Pembelajaran daring itu susah. Materi yang disampaikan oleh guru kurang jelas.

Jika tanya dengan orang tua juga tidak paham dengan materi yang disampaikan oleh guru. Guru menyampaikan materi lewat grup Whatsapp dengan memfoto materi dan tugas.

Peserta didik masih berangggapan materi yang disampaikan secara daring tidak mudah untuk dipahami. Terlebih, orang tua juga kurang memahami materi sehingga tidak dapat mendampingi peserta didik secara maksimal.

Hal senada juga disampaikan oleh salah satu wali murid yang menjadi subjek penelitian juga mengatakan terkait sulitnya pembelajaran daring, khususnya di kelas rendah. Hasil wawancara dengan WM 2 menyebutkan bahwa, "pembelajaran daring sangat sulit diterapkan di kelas II karena belum lancar membaca dan menulis."

Berbeda halnya dengan SW 1, SW 6 mengemukakan hal yang berbeda. Adapun hasil wawancara dengan SW 6 adalah sebagai berikut. 
Jurnal Ilmiah KONTEKSTUAL, Volume.3, No.1, Agustus 2021, pp. 1-7

Pembelajaran dari itu mudah, materi dapat dipahami dengan baik. Tapi, untuk pembelajaran materi matematika sulit dipahami secara daring. Guru menjelaskan dan memberi materi lewat foto dan video youtube.

SW 6 mengemukakan pembelajaran daring yang mudah karena didukung dengan media yang tepat. Akan tetapi, terdapat satu muatan pembelajaran yang sulit dipahami secara daring, yaitu muatan matematika.

\section{Pembahasan}

\section{Model Pembelajaran Daring di SD Negeri Cikakak 01}

Model pembelajaran daring yang dilaksanakan pihak SD Negeri Cikakak 01 Banjarharjo Brebes dilakukan dengan blended. Blended yang dimaksud disini adalah mengkombinasikan antara daring dan luring dalam kegiatan pembelajaran. Blended dapat meningkatkan motivasi peserta didik. Hal ini didukung dengan hasil penelitian terdahulu yang menyebutkan bahwa motivasi siswa meningkat setelah mengikuti pembelajaran dengan menggunakan model pembelajaran blended learning [6].

Model blended ini juga dilaksanakan di tiga SD berbeda di wilayah yang sama, yaitu di kecamatan Banjarharjo. Ketiga sekolah tersebut adalah SDN Cikunya 03, SDN Cigadung 03, dan SDN Ciawi. Hasil penelitian menunjukkan peserta didik tidak hanya melaksanakan pembelajaran secara daring, tetapi juga secara luring. Di ketiga sekolah tersebut, kegiatan luring bukan hanya dimanfaatkan untuk mengumpulkan tugas, tetapi juga untuk mengambil bahan bacaan mengingat masih terbatasnya bahan bacaan yang ada [7]. Oleh sebab itu, model model sangat membantu meminimalisir kendala-kendala yang muncul selama pembelajaran daring.

Selanjutnya platform yang digunakan dalam pembelajaran daring didominasi dengan penggunaan whatsapp. Lebih lanjut, hasil penelitian menunjukkan, bahwa grup whatsapp efektif digunakan dalam pembelajaran daring [8]. Beberapa alasan yang mendasarinya adalah kemudahan penggunaannya sehingga memudahkan pengawasan orang tua juga selama pembelajaran daring.

Platform whatsapp sangat memudahkan komunikasi dalam kegiatan pembelajaran selama daring. Sementara itu, hasil penelitian lain menunjukkan proses komunikasi dalam pembelajaran daring di masa pandemi covid-19 sebenarnya terjadi begitu rumit. Dari pengirim ke penerima pesan diubah dalam bentuk simbolik dan diteruskan lagi ke seluran penerima dan diterjemahkan ulang (decoding), hingga akhirnya sampai kepenerima. [9]. Oleh sebab itu, dalam pembelajaran daring sangat diperlukan platform yang mudah, praktis, dan efisien untuk digunakan, sehingga dapat mendukung pembelajaran daring.

Penggunaan media selama pembelajaran daring tentu sangat dianjurkan. Hal ini mengingat penggunaan media akan membantu peserta didik memahami sesuatu, terlebih yang sifatnya abstrak. Berdasarkan hasil penelitian di SD Negeri Cikakak 01, terdapat dua media yang biasa digunakan yaitu video dan gambar. Video sendiri guru lebih banyak mengakses lewat youtube yang disesuaikan dengan materi pelajaran. Hasil penelitian menyebutkan bahwa media pembelajaran berbasis video dapat meningkatkan pemahaman konsep bagi peserta didik [10]. Video menyajikan perpaduan gambar, suara, bahkan animasi secara bersamaan, sehingga dapat memudahkan peserta didik dalam memahami sesuatu.

Selanjutnya media yang kedua yang biasa digunakan selama pembelajaran daring di SD Negeri Cikakak 01 adalah media gambar. Media gambar ini memang berbeda dengan media video, dalam media gamba ini biasanya terdapat satu atau beberapa gambar yang mendukung materi pelajaran. Tidak hanya itu, media gambar juga dapat dikombinasikan dengan permainan sederhana, sehingga dapat meningkatkan motivasi belajar peserta didik.

Media gambar merupakan media yang sederhana, sehingga dapat dipersiapkan dengan mudah oleh guru sebagai pendidik. Media gambar juga akan memperlanjar proses pembelajaran agar dapat mencapai tujuan pembelajaran [11]. Hal ini disebabkan, penggunaan media gambar akan membantu memvisualkan konsep yang abstrak menjadi konkret, sehingga peserta didik akan lebih mudah memahami konsep. 
Jurnal Ilmiah KONTEKSTUAL, Volume.3, No.1, Agustus 2021, pp. 1-7

\section{Kendala Pembelajaran Daring di SDN Cikakak 01}

Pembelajaran dengan daring masih menimbulkan banyak permasalahan khususnya bagi peserta didik, guru, maupun orangtua murid di SD Negeri Cikakak 01 Banjarharjo. Kendala tersebut yaitu pembelajaran daring masih belum terlalu efektif untuk muatan tertentu dan tingkat kelas tertentu. Kendala ini tentu terjadi karena beberapa faktor penghambat yang muncul.

Muatan pelajaran yang dianggap mengalami kendala selama pembelajaran daring adalah muatan matematika. Hal ini terjadi lantaran dimuatan matematika banyak sekali materi-materi yang perlu dipraktikkan. Peserta didik juga perlu mencoba, bukan hanya melihat penjelasan guru dari video atau gambar yang disajikan. Sementara pada tingkat kelas rendah pembelajaran daring dianggap tidak efektif karena peserta didik masih belum lancar membaca dan menulis.

Kemunculan kendala pelaksanaan pembelajaran daring tentu disebabkan oleh beberapa faktor penghambat. Beberapa faktor penghambat tersebut diantaranya adalah rendahnya penguasaan teknologi khususnya bagi wali murid sehingga tidak dapat mendampingi anakanaknya secara optimal. Disamping itu, dukungan perangkat yang belum memadai, masalah ekonomi, dan komunikasi juga menjadi faktor penghambat dari kendala-kendala yang ada [3].

Selain faktor penghambat yang muncul dari orang tua, guru pun memiliki beberapa faktor penghambat yang mengakibatkan munculnya kendala dalam pembelajaran daring. Faktor penghambat tersebut diantaranya berkaitan dengan platform, perangkat, pengelolaan pembelajaran, dan pengawasan [12]. Penggunaan satu platform, seperti whatsapp saja masih dirasa kurang efektif, karena pembelajaran memerlukan pengawasan dan kerjasaa yang baik antara guru dan orang tua [13].

Pembelajaran yang dilakukan secara daring tidak maksimal karena ada banyak kendala dalam pembelajaran secara daring. Tidak semua peserta didik mempunyai gatget jadi, tidak tahu materi apa yang sudah diberikan oleh guru lewat gawai juga tidak tahu tentang tugas yang sudah diberikan guru. Untuk kelas rendah sangat sulit dalam memhami pelajaran lewat Hand phone karena kelas rendah belum bisa membaca dan menulis terutama kelas 1 . Sinyal dan kuota juga menjadi kendala dalam pembelajran daring. Orang tua yang ekonominya minim sangat susah untuk membeli kuota terus menerus. Oengumpulan tugas walaupun dikeumpulkan kesekolah juga kurang maksimal karena ada bebrapa peserta didik yang tidak mengumpulkan tugas.

\section{SIMPULAN}

Model pembelajaran daring yang dilaksanakan pihak SD Negeri Cikakak 01 Banjarharjo dilaksanakan dengan blended, yaitu perpaduan daring dan tatapmuka. Pembelajaran daring dilaksanakan dengan platform whatsapp dan menggunakan media video atau gambar. Dalam pelaksanaan pembelajaran daring, guru memberikan materi dengan foto-foto materi dan video youtube yang diunggah pada group whatsapp. Selanjutnya untuk penugasan juga melalui grup Whatsapp dan dikumpulkan kesekolah sesuai dengan jadwal yang sudah dibuat.

Kendala dalam pembelajaran daring melalui wahtsapp masih menimbulkan banyak permasalahan khususnya bagi peserta didik di SD Negeri Cikakak 01 Banjarharjo. Kendala tersebut yaitu pembelajaran daring masih belum terlalu efektif untuk muatan tertentu dan tingkat kelas tertentu. Kemunculan kendala ini disebabkan karena beberapa faktor penghambat, diantaranya rendahnya penguasaan teknologi, perangkat yang belum memadai, masalah ekonomi, komunikasi, pengawasan, serta pengelolaan pembelajaran.

\section{DAFTAR PUSTAKA}

[1] H. Putria, L. H. Maula, and D. A. Uswatun, "Analisis proses pembelajaran dalam jaringan (DARING) masa pandemi covid-19 pada guru sekolah dasar," Jurnal basicedu, vol. 4, no. 4, pp. 861-872, 2020, [Online]. Available: https://jbasic.org/index.php/basicedu/article/view/460. 
[2] A. Shoimin, Model Pembelajaran Inovasi dalam Kurikulum 2013. Yogyakarta: Ar-Ruzz Media, 2017.

[3] I. Setyorini, "Pandemi covid-19 dan online learning: apakah berpengaruh terhadap proses pembelajaran pada kurikulum 13?," Journal of Industrial Engineering \& Management Research (JIEMAR), vol. 01, no. 01, pp. 95-102, 2020, [Online]. Available: https://jiemar.org/index.php/jiemar/article/view/31.

[4] W. A. F. Dewi, "Dampak covid-19 terhadap implementasi pembelajaran daring di sekolah dasar," Edukatif: Jurnal Ilmu Pendidikan, vol. 2, no. 1, pp. 55-61, 2020, [Online]. Available: https://edukatif.org/index.php/edukatif/article/view/89.

[5] N. Martono, Metode Penelitian Sosial. Jakarta: Rajawali Pers, 2015.

[6] N. Khoiroh, M. Munoto, and L. Anifah, "Pengaruh model pembelajaran blended learning dan motivasi belajar terhadap hasil belajar siswa," Jurnal Penelitian Ilmu Pendidikan, vol. 10, no. 2, pp. 97-110, 2017, [Online]. Available: https://journal.uny.ac.id/index.php/jpip/article/view/13986.

[7] A. Mumpuni, P. Y. Kurniawan, R. U. Nurbaeti, A. N. Fadillah, M. Yuliyanti, and N. Indriyani, "Implementation of the school literacy movement during the covid-19 pandemic," Premiere Educandum : Jurnal Pendidikan Dasar dan Pembelajaran, vol. 11, no. $1, \quad$ pp. 75-87, 2021, [Online]. Available: http://ejournal.unipma.ac.id/index.php/PE/article/view/7928/0.

[8] N. K. S. Astini, "Pemanfaatan teknologi informasi dalam pembelajaran tingkat sekolah dasar pada masa pandemi covid-19," Jurnal Lampuhyang, vol. 11, no. 2, pp. 13-25, 2020, [Online]. Available: amlapura.ac.id/index.php/jurnallampuhyang/article/view/194.

[9] M. Toharudin, "Komunikasi dalam pembelajaran di era pandemi covid-19," Prosiding Seminar Nasional FIP 2020, vol. 7, no. 9, pp. 238-248, 2020, [Online]. Available: https://fip.unesa.ac.id/fip-ppti/public/proceeding/index.php/webinar2020/article/view/90.

[10] U. Cahyaningsih and I. M. Sofyan, "Pembelajaran berbasis video untuk meningkatkan pemahaman konsep IPA peserta didik di SD," Jurnal Ilmiah KONTEKSTUAL, vol. 02 , no. 02, pp. 77-83, 2021, [Online]. Available: http://jurnal.umus.ac.id/index.php/kontekstual/article/view/400.

[11] A. Amir, "Penggunaan Media Gambar dalam Pembelajaran Matematika," Jurnal Eksakta, vol. 2, no. 1, pp. 34-40, 2016, [Online]. Available: http://jurnal.umtapsel.ac.id/index.php/eksakta/article/view/184.

[12] H. A. Rigianti, "Kendala pembelajaran daring guru sekolah dasar di Kabupaten Banjarnegara," Elementary School, vol. 7, no. 2, pp. 297-302, 2020, [Online]. Available: https://journal.upy.ac.id/index.php/es/article/view/768.

[13] M. Daheri, J. Juliana, D. Deriwanto, and A. D. Amda, "Efektifitas whatsapp sebagai media belajar daring," Jurnal Basicedu, vol. 4, no. 4, pp. 775-783, 2020, [Online]. Available: https://jbasic.org/index.php/basicedu/article/view/445. 